Anna Stach-Siegieńczuk Centrum Wiedzy i Informacii Naukowo-Technicznej przy Wydziale Elektrycznym Politechnika Wrocławska e-mail: anna.stach-siegienczuk@pwr.edu.pl

\title{
Wykorzystanie narzędzi Web 2.0 przez wybrane biblioteki najlepszych uczelni odnotowanych w QS World University Rankings 2013
}

DOI: http://dx.doi.org/10.12775/TSB.2014.023

STRESZCZENIE: Zbadano wykorzystanie technologii Web 2.0 na stronach WWW bibliotek 10 najlepszych uniwersytetów według światowego rankingu uczelni wyższych QS World University Rankings 2013. Analizie poddano narzędzia, które umożliwiają i poprawiają komunikację z użytkownikami. Zbadano m.in. tworzone przez biblioteki fora dyskusyjne, kanały RSS, obecność na portalach społecznościowych (Facebook, Twitter), prowadzenie blogów. Przeanalizowano, w jakim stopniu wybrane narzędzia technologii Web 2.0 były używane przez placówki oraz jakim celom miały służyć. Badania zostały przeprowadzone w okresie od 1 stycznia do 31 lipca 2014 r.

SŁowA KLUCzowe: biblioteka, komunikacja, promocja biblioteki, sieci społeczne, Web 2.0, witryny internetowe bibliotek.

\section{Wprowadzenie} ykorzystanie technologii Web $2.0 \mathrm{w}$ bibliotekach jest tematem
obszernie omawianym w literaturze przedmiotu, m.in. w publika- 
cjach autorstwa Grzegorza Gmiterka ${ }^{1}$, Bożeny Jaskowskiej i Adama Dudczaka $^{2}$, Małgorzaty Filipczak ${ }^{3}$, Danuty Ostrowskiej ${ }^{4}$ czy Anny Sidorczuk i Anny Gogiel-Kuźmickiej ${ }^{5}$. Również autorka niniejszego artykułu przy współpracy z Pauliną Bartosik na przykładzie wybranych europejskich witryn WWW bibliotek uniwersyteckich zbadała wykorzystywanie przez nie technologii Web $2.0^{6}$.

Web 2.0 to według Justyny Walkowskiej:

pojęcie, które w mniejszym stopniu jest związane z technologicznym przełomem, a w większym ze sposobem, w jaki użytkownicy korzystają z sieci [...], nie są oni tylko biernymi odbiorcami [...], stają się ich twórcą: publikują wiadomości na portalach społecznościowych [...], udzielają się na forach dyskusyjnych, dzieląc się opiniami, ale także konkretną wiedzą ${ }^{7}$.

1 G. Gmiterek, Library 2.0. Możliwości zastosowania Web 2.0 w bibliotekach polskich. „Biuletyn EBIB” [online] 2007, nr 4 (85) [dostęp 31 października 2014]. Dostępny w World Wide Web: http://www.ebib.info/2007/85/a.php?gmiterek; tenże, Library 2.0: nowe wyzwanie dla polskich bibliotek, [w:] Oblicza Internetu: architektura komunikacyjna, Elbląg 2007, s. 195-204; tenże, Biblioteka w środowisku społecznościowego Internetu: biblioteka 2.0, Warszawa 2012.

2 B. Jaskowska, A. Dudczak, Library 2.0 - rewolucja i przełom, czy kolejny etap rozwoju współczesnego bibliotekarstwa?, „Przegląd Biblioteczny” 2007, z. 3, s. 354-365.

${ }_{3}$ M. Filipczak, Jak daleko stąd do nowoczesności - w stronę biblioteki drugiej generacji. „Biuletyn EBIB” [online] 2008, nr 1 (92) [dostęp 31 października 2014]. Dostępny w World Wide Web: http://www.ebib.info/2008/92/a.php?filipczak.

${ }^{4}$ D. Ostrowska, Od Web 2.0 do Biblioteki 2.0, „Bibliotekarz” 2008, nr 3, s. 10-13.

5 A. Sidorczyk, A. Gogiel-Kuźmicka, Web 1.0, Web 2.0, czy może już Web 3.0? - narzędzia i technologie informacyjno-komunikacyjne stosowane na stronach WWW bibliotek technicznych szkół wyższych w Polsce. „Biuletyn EBIB” [online], 2012, nr 2 (129) [dostęp 31 października 2014]. Dostępny w World Wide Web: http://www.ebib.pl/images/stories/numery/129/129_sidorczuk.pdf.

${ }^{6}$ Analizie poddano 20 placówek. Przy ich wyborze kierowano się datą powstania poszczególnych uczelni - wybrano tylko dwa uniwersytety o najdłuższej tradycji funkcjonowania w danym państwie. Zasięg terytorialny ograniczono do zachodnich krajów europejskich oraz Polski. Zbadano tworzone przez biblioteki m.in. kanały RSS, obecność na portalach społecznościowych (Facebook, Twitter), prowadzenie blogów, personalizację interfejsu użytkownika. Artykuł zostanie opublikowany w materiałach z II Międzynarodowej Konferencji Naukowej pt. „Biblioteka w przestrzeni edukacyjnej. Bibliotekarz 2.0 nowoczesność na bazie tradycji".

7 J. Walkowska, Jeśli nie Web 2.0, to co?. „Biuletyn EBIB” [online] 2012, nr 2 (129) [dostęp 31 października 2014]. Dostępny w World Wide Web: http://www.nowyebib. info/images/stories/numery/129/129_walkowska.pdf. 
Charakterystyczną cechą Web 2.0 jest więc „zaangażowanie użytkowników w tworzenie treści serwisów, prostota obsługi, łatwość użytkowania oraz zwycięstwo otwartych standardów" ${ }^{\prime \prime}$. Bibliotekarze zaadaptowali niektóre spośród narzędzi charakterystycznych dla technologii Web 2.0, której zasadę oddają słowa Tima O’Reilly'ego: „twórz aplikacje, które lepiej okiełznają sieć, by więcej ludzi ich używało" ${ }^{\prime \prime}$. Narzędzia Web 2.0 są wykorzystywane zarówno w komunikacji wewnętrznej pomiędzy pracownikami, jak i w komunikacji z otoczeniem. W tym miejscu wypada przybliżyć termin Biblioteka 2.0. Według Jacka Manessa (autora tekstu Biblioteka 2.0 w teorii: co Web 2.0 oznacza dla bibliotek) jest to „zastosowanie interaktywnych, współtworzonych oraz multimedialnych technologii sieciowych do udostępniania w Internecie bibliotecznych zasobów i usług”"10. Biblioteka 2.0 „wykorzystuje sieci społeczne jako jedno z narzędzi Web 2.0, lecz sama staje się siecią społeczną: użytkownicy zakładają biblioteczne konta, komunikują się ze sobą, współtworzą i oceniają zasób informacyjny"11. Celem Biblioteki 2.0 jest udostępnianie w sieci usług i zasobów bibliotecznych oraz aktywna komunikacja z użytkownikami ${ }^{12}$. Głównym jej elementem jest strona WWW placówki. Chcąc urozmaicić swoje usługi, książnice korzystają dodatkowo m.in. z ogólnodostępnych serwisów społecznościowych (np. Facebook), blogów, katalogów, forów dyskusyjnych czy pod- i videocastów.

Celem artykułu jest analiza wybranych witryn internetowych bibliotek pod względem wykorzystania przez nie elementów technologii Web 2.0. Zbadano, w jakim stopniu były one używane przez te placówki oraz jakim celom miały służyć. Na potrzeby pracy przeanalizowano strony WWW

${ }^{8}$ M. Miller, E. Mroczek, Profil użytkownika i inne elementy Web 2.0 w bibliotekach cyfrowych. „Biuletyn EBIB” [online] 2007, nr 7 (88) [dostęp 31 października 2014]. Dostępny w World Wide Web: http://www.ebib.info/2007/88/a.php?miller_mroczek.

9 T. O'Reilly, What is Web 2.0 [online] [dostęp 31 października 2014]. Dostępny w World Wide Web: http://www.oreillynet.com/pub/a/oreilly/tim/news/2005/09/30/ what-is-web-20.html.

10 J. M. Maness, Library 2.0 Theory: Web 2.0 and Its Implications for Libraries. [online] [dostęp 31 października 2014]. Dostępny w World Wide Web: http://www.webology. ir/2006/v3n2/a25.html.

11 A. Koszowska, Jack Maness o teorii Biblioteki 2.0 oraz o tym, co Web 2.0 oznacza dla bibliotek. „Biuletyn EBIB” [online] 2007, nr 4 (85) [dostęp 31 października 2014]. Dostępny w World Wide Web: http://www.ebib.info/2007/85/a.php?koszowska.

12 A. Sidorczyk, A. Gogiel-Kuźmicka, dz. cyt. 
zagranicznych bibliotek uniwersyteckich. Przy ich wyborze kierowano się światowym rankingiem uczelni wyższych QS World University Rankings 2013, który odzwierciedla jakość 800 uczelni z całego świata i jest oparty na analizie takich wskaźników, jak: reputacja naukowa placówki, liczba cytowań, ocena absolwentów uczelni przez ich pracodawców, stosunek liczby pracowników do liczby studentów, liczba zatrudnionych zagranicznych wykładowców, liczba studentów z innych krajów, którzy studiują na danej uczelni ${ }^{13}$.

\section{Strony internetowe bibliotek poszczególnych uczelni}

Analizie poddano pierwszych 10 uczelni występujących w rankingu. Ponieważ miejsce ostatnie ex aequo zajęły 2 placówki, w pracy zbadano 11 witryn WWW bibliotek głównych. Były to:

1. Massachusetts Institute of Technology Libraries (dalej: MIT Libraries, USA) ${ }^{14}$,

2. Harvard Library (USA) ${ }^{15}$,

3. Cambridge University Library (Wielka Brytania) ${ }^{16}$,

4. University College London Library (dalej: UCL Library, Wielka Brytania) ${ }^{17}$,

5. Imperial College London Library (Wielka Brytania) ${ }^{18}$,

6. Bodleian Libraries (Wielka Brytania) ${ }^{19}$,

13 QS World University Rankings 2013 [online] [dostęp 31 października 2014]. Dostępny w World Wide Web: http://www.iu.qs.com/university-rankings/world-universityrankings/.

${ }^{14}$ MIT Libraries [online] [dostęp 31 października 2014]. Dostępny w World Wide Web: http://libraries.mit.edu/.

${ }^{15}$ Harvard Library [online] [dostęp 31 października 2014]. Dostępny w World Wide Web: http://lib.harvard.edu/.

${ }^{16}$ Cambridge University Library [online] [dostęp 31 października 2014]. Dostępny w World Wide Web: http://www.lib.cam.ac.uk/.

17 UCL Library services [online] [dostęp 31 października 2014]. Dostępny w World Wide Web: http://www.ucl.ac.uk/library/.

${ }^{18}$ Imperial College London Library [online] [dostęp 31 października 2014]. Dostępny w World Wide Web: http://www3.imperial.ac.uk/library.

${ }_{19}$ Bodleian Libraries University of Oxford [online] [dostęp 31 października 2014]. Dostępny w World Wide Web: http://www.bodleian.ox.ac.uk/home. 
7. Stanford University Libraries (USA) ${ }^{20}$,

8. Yale University Library (USA) ${ }^{21}$,

9. University of Chicago Library (USA) ${ }^{22}$,

10. California Institute of Technology Library (dalej: Caltech Library, USA) ${ }^{23}$,

11. Princeton University Library (USA) ${ }^{24}$.

Dla rozróżnienia bibliotek uniwersyteckich w artykule pozostawiono nazwy własne instytucji w rodzimych językach.

Witryna internetowa biblioteki uczelnianej powinna być jej wizytówką. W skomputeryzowanym świecie potencjalny użytkownik pierwszy kontakt z biblioteką rozpoczyna właśnie poprzez jej stronę WWW, orientuje się, czy dana placówka odpowiada jego potrzebom, a następnie zaczyna z niej korzystać. Strona WWW biblioteki, zwłaszcza uczelnianej, powinna spełniać zdaniem Dagmary Sawickiej funkcję prezentacyjną, promocyjną, informacyjną, edukacyjną, ogólnorozwojową, komunikacyjną i doradczą ${ }^{25}$. Według Grażyny Piotrowicz powinna ona odgrywać rolę informacyjno-promocyjną i usługową ${ }^{26}$.

Podstawowym założeniem witryny internetowej jest jej charakter informacyjny. Chcąc sprostać temu założeniu, koniecznym warunkiem jest przejrzystość i nawigacja, harmonijny układ elementów na stronie oraz prawidłowy układ typograficzny i graficzny.

20 Stanford University Libraries [online] [dostęp 31 października 2014]. Dostępny w World Wide Web: http://library.stanford.edu/.

${ }^{21}$ Yale University Library [online] [dostęp 31 października 2014]. Dostępny w World Wide Web: http://web.library.yale.edu/.

22 University of Chicago Library [online] [dostęp 31 października 2014]. Dostępny w World Wide Web: http://www.lib.uchicago.edu/e/index.html.

${ }^{23}$ Caltech Library [online] [dostęp 31 października 2014]. Dostępny w World Wide Web: http://library.caltech.edu/.

${ }^{24}$ Princeton University Library [online] [dostęp 31 października 2014]. Dostępny w World Wide Web: http://library.princeton.edu/.

25 D. Sawicka, Funkcje witryny internetowej biblioteki akademickiej, „Praktyka i Teoria Informacji Naukowej i Technicznej" 2005, nr 1, s. 13-19.

${ }^{26}$ G. Piotrowicz, Bibliotekarz a „użytkownik - klient” we współczesnej bibliotece uczelnianej. W: Czytelnik czy klient? Ogólnopolska konferencja bibliotekarzy, Toruń, 4-6 grudnia 2003 r. (Materiały konferencyjne EBIB, nr 7) [online]. Warszawa: Komisja Wydawnictw Elektronicznych SBP, 2003 [dostęp 31 października 2014]. Dostępny w World Wide Web: http://ebib.oss.wroc.pl/matkonf/torun/piotrowicz.php. 
Elementy, jakie przebadano na potrzeby niniejszego artykułu, to: serwisy społecznościowe, takie jak Facebook (umożliwiający tworzenie własnego profilu, który staje się wizytówką właściciela, pozwala na dzielenie się wiadomościami i zdjęciami), Twitter (czyli „aktualizowana w czasie rzeczywistym sieć informacyjna dostarczająca nowe wydarzenia, pomysły, opinie na różne tematy, w której można umieszczać krótkie wiadomości ograniczone do 140 znaków"27), YouTube (pozwala instytucjom i osobom dzielić się filmami z innymi użytkownikami Internetu), Flickr (umożliwia dzielenie się filmami i zdjęciami, które mogą zostać ocenione przez oglądających), Instagram (dzięki niemu użytkownicy mogą robić zdjęcia, stosować do nich filtry cyfrowe oraz udostępniać je w różnych serwisach społecznościowych ${ }^{28}$ ), Pinterest (przeznaczony do kolekcjonowania i porządkowania zebranych materiałów wizualnych) ${ }^{29}$, Google+ (narzędzie ułatwiające współdzielenie treści, swoista konkurencja dla wyżej omówionego Facebooka) ${ }^{30}$. Analizie zostały poddane także blogi bibliotek, za pomocą których prezentowane są subiektywne opinie, aktualności, relacje z wystaw. Są one ujęte w formie chronologicznie zamieszczanych wiadomości. Jak podaje G. Gmiterek: „na treść internetowych dzienników mogą składać się teksty pisane przez bibliotekarzy dziedzinowych i czytelników [...] artykuły dotyczące aktualnych wydarzeń, internetowe szkolenia, ukazanie działalności informacyjnej"31 oraz elementy takie, jak odsyłacze do innych serwisów, najważniejsze informacje dotyczące biblioteki (np. godziny otwarcia, dane teleadresowe). Kolejnym narzędziem poddanym analizie była obecność i wykorzystanie platform e-learningowych (będących rodzajem zdalnej działalności dydaktycznej, wspomaganej m.in. przez wykorzystanie „poczty elektronicznej, forów internetowych, komunikatorów czy czatów [...], gdzie wykład lub pokaz

27 Twitter - o nas [online] [dostęp 31 października 2014]. Dostępny w World Wide Web: https://twitter.com/about.

${ }^{28}$ Instagram [online] [dostęp 31 października 2014]. Dostępny w World Wide Web: http://instagram.com/\#.

${ }_{29}$ Pinterest [online] [dostęp 31 października 2014]. Dostępny w World Wide Web: http://about.pinterest.com/en.

${ }^{30}$ C. C. Miller, Another Try by Google to take on Facebook. „The New York Times Business Day Technology" [online] 2011, June [dostęp 31 października 2014]. Dostępny w World Wide Web: http://www.nytimes.com/2011/06/29/technology/29google. html?_r=2\&.

31 G. Gmiterek, Biblioteka w środowisku społecznościowego Internetu..., s. 143. 
zastępują: prezentacja, informacje tekstowe, nagrania, zaś ćwiczenia wypierane są przez różnego rodzaju zadania, testy czy quizy"32). Analizowano katalogi OPAC 2.0 (które działają „na podobnej zasadzie jak popularne wyszukiwarki internetowe [...], [a które zostały] wzbogacone o elementy interaktywne, np. tworzenie zakładek (bookmarks) i list ulubionych tytułów oraz możliwość ich przechowywania na swoich kontach e-mail, a także o dostęp do historii wyszukiwania, możliwość oceniania, recenzowania, tagowania"33), kanały RSS (ang. Really Simple Syndication, które „umożliwiają szybki dostęp do ogromnych zasobów informacyjnych"34, aplikacja polega na „publikowaniu przez dany serwis informacji w specjalnym, ujednoliconym formacie opartym na języku XML, [...] mogą być [one] później przechwycone i agregowane przy pomocy specjalnych programów - czytników”35), podcasty (czyli „audycje dostępne przez Internet w postaci odcinków w plikach audio: najczęściej w formacie mp3 bądź wideo" ${ }^{36}$ ). Omówione zostały także zastosowane usługi asynchroniczne (czyli „realizowane za pomocą poczty elektronicznej, [które] cechują się brakiem bezpośredniej komunikacji z bibliotekarzem i wydłużonym czasem otrzymania odpowiedzi"37, w tym mieszczą się wszelkiego rodzaju formularze, np. zapytaj bibliotekarza, zaproponuj zakup książki) i usługi synchroniczne (czyli takie, w których udzielane są informacje w czasie rzeczywistym, kiedy następuje natychmiastowa interakcja między użytkownikiem a bibliotekarzem - jak w chacie ${ }^{38}$ ).

W badaniach zastosowano metodę jakościowo-heurystyczną ${ }^{39}$, polegającą na analizie i ocenie zjawiska na podstawie określonych kryteriów.

32 A. Sidorczyk, A. Gogiel-Kuźmicka, dz. cyt.

33 Tamże.

${ }^{34}$ R. Ścisłowski, RSS: wiedzieć wszystko w ciagu 5 minut! [online] [dostęp 31 października 2014]. Dostępny w World Wide Web: http://www.pcworld.pl/news/80538. html.

35 Tamże.

36 Podcast - a co to jest? [online] [dostęp 31 października 2014]. Dostępny w World Wide Web: http://podcastsportowy.wordpress.com/podcast-a-co-to-jest/.

${ }^{37}$ L. Derfert-Wolf, Elektroniczne usługi informacyjne typu pytanie-odpowiedź - światowe trendy i doświadczenia bibliotek. „Biuletyn EBIB” [online] 2006, nr 1 (71) [dostęp 31 października 2014]. Dostępny w World Wide Web: http://www.ebib.info/2006/71/ derfert.php.

${ }^{38}$ M. Miller, E. Mroczek, dz. cyt.

39 B. Bednarek-Michalska, Ocena jakości bibliotekarskich serwisów informacyjnych udostępnianych w Internecie. „Biuletyn EBIB” [online] 2002, nr 2 (31) [dostęp 31 paź- 
Elementami podlegającymi ocenie stały się m.in. dostępność do usług ze strony głównej, gdzie znajdują się informacje, czy jej odnalezienie stanowi problem oraz czy jest umieszczona w widocznym miejscu, oraz częstotliwość korzystania z usług biblioteki.

Szukając podobieństw i różnic w badanych stronach WWW, wykorzystano metodę porównawczą. Elementy metody statystycznej znalazły zastosowanie w niniejszej pracy w ilościowej analizie danych. Pomogła ona przy oznaczeniu stopnia wykorzystania poszczególnych narzędzi technologii Web 2.0.

\section{Serwisy społecznościowe i internetowe}

Biblioteki, chcąc pozyskać nowych użytkowników oraz zachęcić ich do korzystania ze swoich usług, zaczynają w coraz większym stopniu korzystać z serwisów społecznościowych. Termin serwis społecznościowy został po raz pierwszy użyty w Stanach Zjednoczonych w latach 50. ubiegłego wieku przez Johna Burnsa, który w swojej definicji ograniczał liczebność grupy do ok. 50-150 osób połączonych wspólnym zadaniem, pracą $^{40}$. Z kolei G. Gmiterek mianem tym określił „,rodzaj interaktywnych stron WWW, które są współtworzone przez sieci społeczne osób podzielających wspólne zainteresowania lub odczuwających potrzebę poznania zainteresowań innych (bez określenia liczebności grupy)”41.

Bardzo popularnym serwisem społecznościowym o charakterze globalnym, wykorzystywanym przez biblioteki jest Facebook ${ }^{42}$. Z poddanych badaniom 11 bibliotek głównych 9 miało tam swoją wizytówkę. Konta

dziernika 2014]. Dostępny w World Wide Web: http://www.ebib.pl/biuletyn-ebib/31/a. php?bednarek_michalska.

40 J. Hetman, Modele serwisów społecznościowych [online]. Warszawa: Polska Agencja Rozwoju Przedsiębiorczości 2009, 10 s. [dostęp 31 października 2014]. Dostępny w World Wide Web: http://www.web.gov.pl/g2/big/2010_02/fe231c5914c783f94d682ba79379bac8.pdf.

${ }^{41}$ G. Gmiterek, Biblioteka w środowisku społecznościowego Internetu..., s. 134.

${ }^{42}$ Choć trzeba pamiętać, że jeszcze do niedawna miejsce lidera w Polsce zajmował portal „Nasza Klasa”. Zob. Google, Facebook i Allegro traca. NK.pl wypadła z top10 [online]. wirtualnemedia.pl [dostęp 31 października 2014]. Dostępny w World Wide Web: http://www.wirtualnemedia.pl/artykul/google-facebook-i-allegro-traca-nk-pl-wypadlaz-top10\#. 
na Facebooku nie założyły Harvard Library (jedynie Harvard-Yenching Library) oraz Stanford University Libraries (chociaż niektóre biblioteki wydziałowe posiadały swoje własne profile).

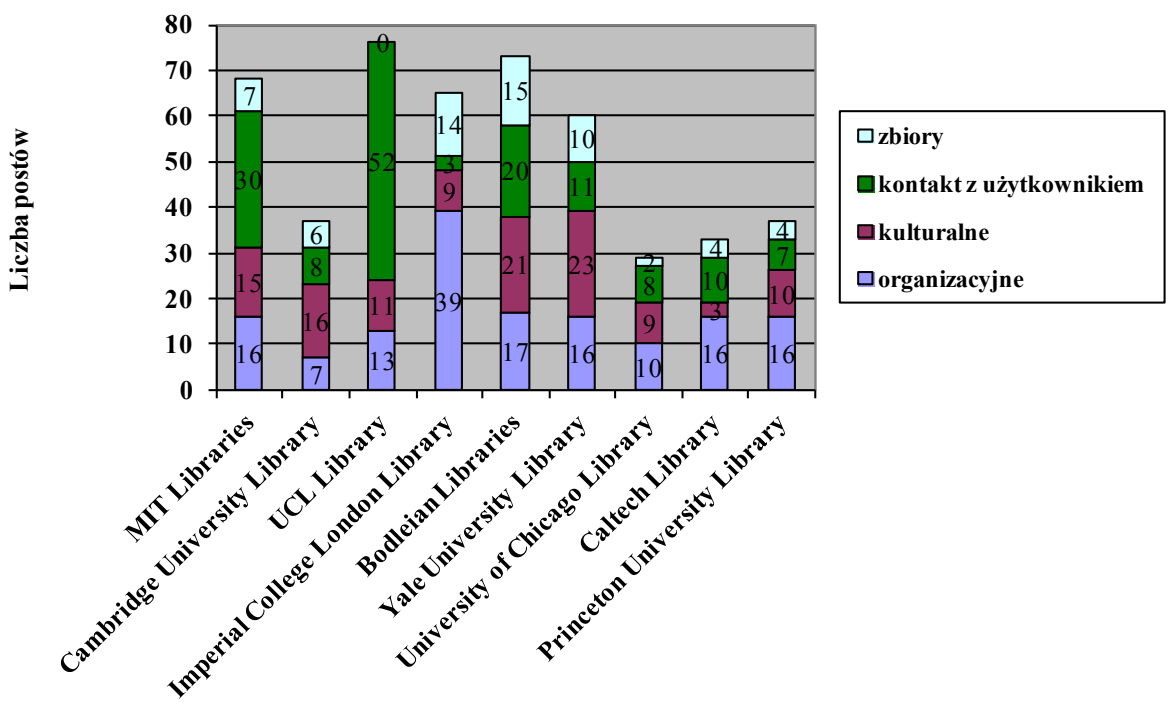

Biblioteki

Wykres 1. Tematyka wpisów w profilach bibliotek w serwisie Facebook Źródło: Opracowanie własne.

Poziom wykorzystania przez biblioteki tablicy w portalu Facebook określić można jako intensywny (średnio umieszczano wiadomości co 2 , 3 dni). Najwięcej wpisów w badanym okresie opublikowała UCL Library (76), najmniej University of Chicago Library (29). Najwcześniej swoje konto w tym serwisie założyła MIT Libraries (13 listopada 2007 r.), najpóźniej University of Chicago Library (26 sierpnia 2012 r.). Jak obrazują dane z wykresu 1, możliwości promocyjne serwisu Facebook zostały wykorzystane przez badane biblioteki w różnym stopniu. W czterech przypadkach posłużył on głównie jako źródło informacji dotyczących organizacji bibliotek, takich jak godziny otwarcia, zmiana lokalizacji (Imperial College London Library, University of Chicago Library, Caltech Library, Princeton University Library). Z kolei MIT Libraries i UCL Library skupiły się na nawiązaniu kontaktu z użytkownikiem. Za pośrednictwem 
tablicy bibliotekarze m.in. składali życzenia użytkownikom z okazji Dnia Prezydenta. Z kolei w 3 przypadkach Facebook służył informowaniu o imprezach kulturalnych mających miejsce na terenie bibliotek. Trudno jednak określić, które z tych podejść było najlepsze. Do uzyskania bardziej wiarygodnych wyników należałoby przeprowadzić analizę z uwzględnieniem dłuższego przedziału czasowego oraz z większą liczbą bibliotek.

Drugim często używanym przez biblioteki serwisem był Twitter. Poziom wykorzystania przez biblioteki tablicy tego portalu również był intensywny (średnio umieszczano wiadomości co 2, 3 dni). Na Tweeterze konto miało 9 placówek - wyjątek stanowiły University of Chicago Library oraz Caltech Library. Biblioteki umieszczały informacje, które w większości przypadków pokrywały się z tymi publikowanymi na Facebooku. Były to przede wszystkim „tweety” dotyczące spraw organizacyjnych. Twitter miał również pomagać nawiązać i utrzymać kontakt z użytkownikiem. W mniejszym stopniu byłźródłem informacji o zbiorach. Biblioteki udostępniały również wpisy użytkowników, których wiadomości w swej treści nawiązywały do placówki (ok. 30\% wszystkich publikowanych wiadomości).

Biblioteki zakładały również konta w serwisie YouTube. Wykorzystały go jedynie 3 placówki: Bodleian Libraries (57 filmów), Harvard Library (20), UCL Library (13). Zamieszczone materiały dotyczyły głównie wydarzeń mających miejsce na terenie bibliotek, jak np. wystawy, materiały dotyczące zdigtalizowanych kolekcji, obsługi urządzeń (skaner, drukarka). Częstotliwość ukazywania się filmów była różna. Średnio umieszczano kilka filmów na rok.

Kolejnym serwisem wykorzystywanym przez placówki był Flickr. Swoje konta w nim miały 2 placówki: MIT Libraries (na koncie ok. 2 tys. zdjęć) oraz Cambridge University Library (73). Fotografie zamieszczane przez biblioteki dotyczyły głównie samych placówek, przedstawiały ich wnętrza, pracowników, użytkowników, czy jak w przypadku MIT Libraries - samego Bostonu.

Mniej popularny wśród bibliotek okazał się serwis Instagram. Korzystały z niego jedynie UCL Institute of Archaeology Library ${ }^{43}$ oraz

43 Ioalibrary [online] [dostęp 31 października 2014]. Dostępny w World Wide Web: http://instagram.com/ioalibrary. 
Imperial College London Library ${ }^{44}$. Częstotliwość publikowania zdjęć przez te placówki nie była duża. Obie zaczęły korzystać z tego serwisu od 2013 r. UCL Institute of Archaeology Library zamieściła 39 zdjęć, a Imperial College London Library - 42. Pierwsza biblioteka informowała użytkowników o swoich zbiorach oraz pomieszczeniach bibliotecznych, z kolei druga z nich umieściła fotografie pochodzące głównie z imprez mających miejsce na terenie placówki.

Następnym serwisem, z którego korzystali bibliotekarze, był Pinterest. Był on wykorzystywany od 2012 r. przez Cambridge University Library, a od 2013 r. przez Bodleian Libraries. Pierwsza placówka na 12 tablicach umieściła w sumie 1363 tzw. piny/pinezki, a Bodleian Libraries na 19 tablicach - 467. Każda z bibliotek skupiła się na innym aspekcie. Bodleian Libraries w 28\% wpisów (132 piny) informowała swoich użytkowników o bibliotece, wydarzeniach mających w niej miejsce, a w 26\% (122 linki) o nowościach na blogach prowadzonych przez bibliotekę. Jedynie 10\% zawartości (48 pinów) stanowiły informacje o zbiorach. Z kolei Cambridge University Library postawiła na informacje o zbiorach w formie elektronicznej (80\%, co stanowiło 1094 linków) i drukowanej (15\%, czyli 209 pinezek). 50 pinezek (4\%) dotyczyło samej biblioteki.

Ostatnim serwisem, z którego korzystała tylko jedna biblioteka z tych poddanych analizie, był Google+. Od 2013 r. korzystała z niego Bodleian Libraries, która umieściła 73 posty, z czego 9 stanowiły pliki wideo dotyczące głównie architektury biblioteki. Pozostałe informacje i zdjęcia dotyczyły w $81 \%$ (50 postów) wydarzeń i wystaw mających miejsce w bibliotece, w 19\% (14 postów) danych o zbiorach ${ }^{45}$.

Posiadanie strony WWW w wyżej omówionych serwisach było swojego rodzaju wizytówką biblioteki, formą kontaktu z użytkownikami, którzy informowani byli o wszelkiego rodzaju wydarzeniach mających miejsce w danej placówce czy zakupionych nowościach wydawniczych. Mimo że stopień wykorzystania witryn przez biblioteki był różny, godny odnotowania jest fakt, że placówki posługiwały się coraz nowszymi na-

${ }^{44}$ Imperiallibrary [online] [dostęp 31 października 2014]. Dostępny w World Wide Web: http://instagram.com/imperiallibrary.

45 Bodleian Libraries [online] [dostęp 31 października 2014]. Dostępny w World Wide Web: https://plus.google.com/109845385592136330696/posts?ppaa=true. 
rzędziami celem pozyskania i utrzymania użytkowników, a przez to stawały się w ich oczach bardziej nowoczesne.

\section{Blogi bibliotek}

Następnym rodzajem narzędzia Web 2.0 wykorzystywanym przez biblioteki był dziennik internetowy - blog. Był on prowadzony jedynie przez 6 bibliotek: Stanford University Libraries ${ }^{46}$, Cambridge University Library ${ }^{47}$, Princeton University Library ${ }^{48}$, UCL Library ${ }^{49}$, Caltech Library ${ }^{50}$, MIT Libraries ${ }^{51}$. Najdłużej swój internetowy dziennik prowadziła Caltech Library (od stycznia 2005 r.), najkrócej Stanford University Libraries (lipiec 2008 r.). Blogi w większości przypadków prowadzone były na bieżąco. Jeśli chodzi o częstotliwość zamieszczania postów, wyróżniały się MIT Libraries (średnio codziennie zamieszczano 1 wiadomość), Stanford University Libraries oraz Caltech Library (co parę dni). W pozostałych przypadkach posty ukazywały się kilka razy w miesiącu. Analizie poddano również tematykę postów, co odzwierciedla wykres 2. Na wykresie nie uwzględniono Princeton Library ze względu na niską liczbę postów (6) w badanym okresie (od 1 stycznia do 31 lipca 2014 r.) oraz Cambridge Libraries ze względu na wysoką liczbę (łącznie opublikowano w badanym okresie 348 wpisów dotyczących zbiorów, 12 dotyczących aktualności w bibliotece i $10 \mathrm{z}$ wydarzeń w środowisku akademickim) ${ }^{52}$.

${ }^{46}$ Stanford Libraries Blog [online] [dostęp 31 października 2014]. Dostępny w World Wide Web: http://library.stanford.edu/blogs/stanford-libraries-blog.

${ }^{47}$ Cambridge University Library blogs [online] [dostęp 31 października 2014]. Dostępny w World Wide Web: http://www.lib.cam.ac.uk/blogs/index.php.

${ }^{48}$ Mudd Manuscript Library Blog [online] [dostęp 31 października 2014]. Dostępny w World Wide Web: https://blogs.princeton.edu/mudd/.

${ }^{49}$ Blogs at UCL Library Services [online] [dostęp 31 października 2014]. Dostępny w World Wide Web: http://blogs.ucl.ac.uk/events/about-this-blog//.

${ }^{50}$ Caltech Library news and updates [online] [dostęp 31 października 2014]. Dostępny w World Wide Web: http://library.caltech.edu/news/index.php/archives/ date $/ 2005 / 01$.

${ }^{51}$ MIT Libraries news [online] [dostęp 31 października 2014]. Dostępny w World Wide Web: http://libraries.mit.edu/news/date/2014/01/.

${ }^{52}$ W Cambridge University Library prowadzono 14 blogów z podziałem na tematykę, m.in. dotyczącą źródeł elektronicznych lub poszczególnych oddziałów w bibliotece, 
Jeśli chodzi o tematykę postów, w większości przypadków dominowały wpisy dotyczące zbiorów bibliotek oraz wydarzeń mających miejsce na uczelni. Biblioteki za pośrednictwem swoich blogów informowały także o wszelkiego rodzaju imprezach mających miejsce na ich terenie, takich jak wystawy czy szkolenia.

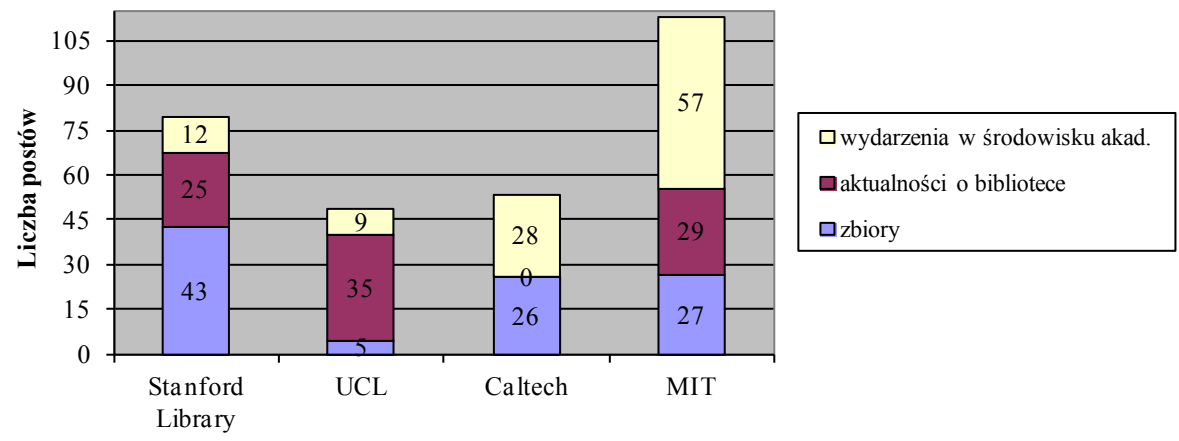

Biblioteka

Wykres 2. Tematyka postów zamieszczanych na blogach

Źródło: Opracowanie własne.

Placówki, takie jak Bodleian Libraries ${ }^{53}$, Harvard Library ${ }^{54}$, Yale University Libraries ${ }^{55}$, zamiast bloga udostępniały newslettery i kalendarze. W tych przypadkach użytkownik miał również dostęp do archiwalnych postów, z których mógł dowiedzieć się o wydarzeniach, kursach czy wystawach mających miejsce na terenie biblioteki. Dodatkowo drogą elektroniczną UCL Library udostępniała miesięcznik „Library news onli-

jak np. biblioteki medycznej. Na uwagę zasługuje fakt, że 6 z nich nie jest już aktualizowanych. W większości przypadków były one bowiem realizowane przy okazji konkretnego projektu, np. dotyczącego skatalogowania zbiorów Siegfried Sassoon.

${ }^{53}$ What's on [online] [dostęp 31 października 2014]. Dostępny w World Wide Web: http://www.bodleian.ox.ac.uk/whats-on.

${ }^{54}$ Library Staff News and Events [online] [dostęp 31 października 2014]. Dostępny w World Wide Web: http://library.harvard.edu/blog/harvard-library.

55 Yale University Library News [online] [dostęp 31 października 2014]. Dostępny w World Wide Web: http://www.library.yale.edu/librarynews/. 
ne"56 - tworzony przez pracowników biblioteki i zawierający artykuły na temat wydarzeń odbywających się w bibliotece lub przybliżający sylwetki samych bibliotekarzy. Od 1999 r. w sieci ukazało się 35 numerów.

\section{E-learning}

Następnym elementem poddanym analizie był e-learning. W większości przypadków biblioteki oferowały możliwość zapisania się drogą elektroniczną na kursy. Przykładowo taka opcja istniała w Cambridge University Library $^{57}$, UCL Library ${ }^{58}$, Bodleian Libraries ${ }^{59}$, Caltech Library ${ }^{60}$. Szkolenia prowadzone były na terenie danej biblioteki, a użytkownik mógł wybrać jedynie dogodny dla niego termin oraz tematykę. Zakres szkoleń był różnorodny: od kursów dotyczących korzystania z e-booków czy ze źródeł elektronicznych (jak w Oxford Library), po szkolenia biblioteczne i tworzenie bibliografii (jak w przypadku Caltech Library). Największą listę zajęć zaproponowała Cambridge Library (dotyczyły one szkolenia bibliotecznego, kolekcji zbiorów chińskich lub kartograficznych dostępnych w bibliotece, zasobów Internetu, w tym wykorzystywania w pracy mediów społecznościowych). W tych przypadkach możliwy był tylko 1 termin zapisu. Camridge Library prowadziła także zapisy na wycieczkę po bibliotece (22). Z kolei MIT Libraries za pośrednictwem prezentacji dostępnych na stronie WWW zaoferowała szkolenie z zakresu Web of Science ${ }^{61}$, a UCL - z zakresu Library Open Access ${ }^{62}$.

${ }^{56}$ Library news online [online] [dostęp 31 października 2014]. Dostępny w World Wide Web: http://www.ucl.ac.uk/library/Newsletter/archive.shtml.

57 Theme: Information Skills [online] [dostęp 31 października 2014]. Dostępny w World Wide Web: http://www.training.cam.ac.uk/cul/theme/infoskills?providerId=119246.

58 Information Skills Training [online] [dostęp 31 października 2014]. Dostępny w World Wide Web: http://www.ucl.ac.uk/library/infoskill.shtml.

59 Workshops and Classes [online] [dostęp 31 października 2014]. Dostępny w World Wide Web: http://ox.libguides.com/content.php?pid=289070\&sid=2376530.

${ }^{60}$ Caltech Library Course Offerings - Spring '14 Classes [online] [dostęp 31 października 2014]. Dostępny w World Wide Web: http://library.caltech.edu/learning/.

61 Video tutorials and workshops [online] [dostęp 31 października 2014]. Dostępny w World Wide Web: http://libguides.mit.edu/video.

62 Projects, events and training [online] [dostęp 31 października 2014]. Dostępny w World Wide Web: http://www.ucl.ac.uk/library/open-access/events. 


\section{Katalogi OPAC 2.0}

W większości analizowanych katalogów bibliotecznych wykorzystywane były różne narzędzia pomocne w przeszukiwaniu zasobów bibliotek. Ich wybór obrazuje wykres 3. Przykładowo katalogi 9 bibliotek zamieszczały odnośniki do zasobów internetowych znajdujących się na stronach Google Books. Tej opcji nie zauważono w UCL Library oraz w Caltech Library. W 5 innych przypadkach czytelnik mógł zapoznać się ze streszczeniami czy spisami treści wyszukanych pozycji. Taką możliwość stworzyły Harvard Library, Imperial College London Library, Stanford University Libraries, Caltech Library, Princeton University Library.

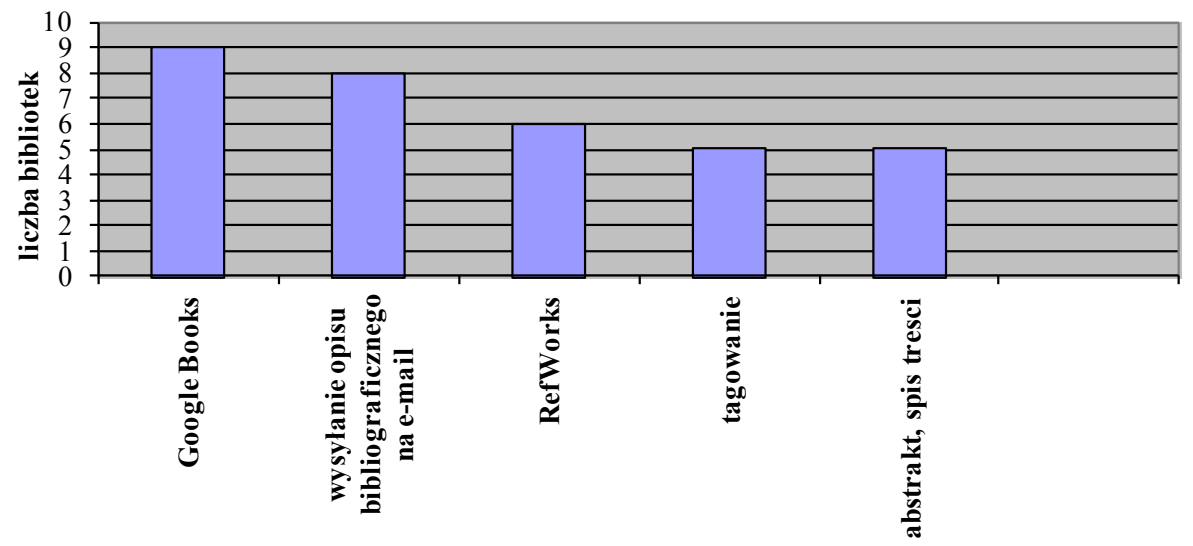

Wykres 3. Elementy OPAC 2.0

Źródło: Opracowanie własne.

Tagowanie opisów zaproponowało użytkownikom 5 bibliotek (Harvard Library, Cambridge University Library, Imperial College London Library, Bodleian Libraries, University of Chicago Library). Eksportowanie opisów bibliograficznych do menedżera bibliografii RefWorks umożliwiło 6 bibliotek: MIT Libraries, Harvard Library, Cambridge University Library, UCL Library, Imperial College London Library, Stanford University Libraries. Z kolei opcję wysłania opisu bibliograficznego znalezionego dokumentu na własną pocztę e-mail oferowało 8 bibliotek (wyjątek to 
Cambridge University Library, Bodleian Libraries, Caltech Library). Stanford University Libraries, Caltech Library, University of Chicago Library, Harvard Library stworzyły możliwość przesłania opisu bibliograficznego na telefon komórkowy. Pozostałe biblioteki uniwersyteckie pozwalały jedynie na przeszukiwanie własnych katalogów elektronicznych.

\section{Kanaly RSS}

Wszystkie poddane analizie biblioteki wykorzystały kanały RSS. Dzięki ich zastosowaniu po wybraniu interesującego zagadnienia następowało przekierowanie do strony źródłowej. Kanały te umożliwiły zaoszczędzenie czasu czytelnika poprzez „eliminację konieczności codziennego przeglądania wielkiej liczby witryn i szukania informacji, zwłaszcza aktualności"63. Najczęściej bibliotekarze na witrynach upowszechniali wiadomości dotyczące wydarzeń i szkoleń odbywających się w bibliotece.

\section{Podcasty}

Bibliotekarze w placówkach, które objęto analizą, w nielicznych przypadkach wykorzystywali technikę wideo, a ściślej podcasty (klipy). Mimo że stanowią one atrakcyjną formę przekazu informacji i jednocześnie edukacji oraz umożliwiają „poszerzenie oferty biblioteki dla osób niepełnosprawnych" ${ }^{\prime 4}$, jedynie w MIT Libraries ${ }^{65}$, UCL Library ${ }^{66}$, Cambridge

${ }^{63}$ L. Derfert-Wolf, Blogi i RSS dla bibliotekarzy i bibliotek. „Biuletyn EBIB” [online] 2007, nr 7 (88) [dostęp 31 października 2014]. Dostępny w World Wide Web: http:// www.ebib.info/2007/88/a.php?derfert.

${ }_{64}$ M. Filas, Elektroniczna komunikacja między bibliotekami a użytkownikami [online] [dostęp 31 października 2014]. Dostępny w World Wide Web: http://skryba.inib.uj.edu. pl/wydawnictwa/e06/filas.pdf.

65 About us. Mission [online] [dostęp 31 października 2014]. Dostępny w World Wide Web: http://libraries.mit.edu/about/; Video tutorials \& workshops [online] [dostęp 31 października 2014]. Dostępny w World Wide Web: http://libguides.mit.edu/video/.

${ }^{66}$ Videos [online] [dostęp 31 października 2014]. Dostępny w World Wide Web: http://www.ucl.ac.uk/library/video.shtml. 
University Library ${ }^{67}$ zostały one zastosowane. Dostępne pliki przedstawiały placówki (wnętrza), ich misję i strategię.

Dzięki wykorzystaniu podcastów użytkownik, odwiedzając bibliotekę po raz pierwszy, „czuje się o wiele swobodniej [...] zna już całe otoczenie biblioteki z filmu, który wcześniej oglądał, nie czuje się już intruzem w nieznanej mu instytucji pełnej książek, ale przychodzi do drzwi biblioteki z pewną dozą pewności siebie i wie, czego może oczekiwać za jej progiem" ${ }^{68}$. W przypadku Harvard Library, UCL Library, Bodleian Libraries na stronie WWW ulokowano odnośnik do serwisu YouTube. W Bodleian Libraries ciekawostką było z kolei umieszczenie listy filmów, które były kręcone w jej pomieszczeniach, jak np. Harry Potter i Kamień Filozoficzny ${ }^{69}$.

\section{Usługi asynchroniczne i synchroniczne}

Bibliotekarze w komunikacji między użytkownikami wykorzystują usługi asynchroniczne. Wszystkie analizowane witryny podawały kontakt e-mail do oddziałów w bibliotece lub do konkretnego bibliotekarza.

Do komunikacji z użytkownikiem wiele bibliotek wykorzystywało również formularze elektroniczne typu „Zapytaj bibliotekarza” (ang. Ask a librarian) i „Zaproponuj tytuł” (ang. Suggest a title). W przypadku analizowanych bibliotek formularze te składały się z tematu wiadomości, treści pytania, danych kontaktowych (adres poczty elektronicznej, numer telefonu). Na wszystkich analizowanych stronach WWW pytania i odpowiedzi były archiwizowane i pojawiały się w postaci tzw. listy FAQ (ang. Frequently Asked Questions). Popularne były także formularze, które umożliwiały złożenie zamówienia na zakup nowej książki. Taką opcję wykorzystano we wszystkich placówkach.

W badanych witrynach umieszczono różnego rodzaju formularze, które miały za zadanie m.in. zbadanie opinii na temat placówki. Taką opcję wykorzystały: Harvard Library, Cambridge University Library, Im-

${ }^{67}$ Welcome to the University Library [online] [dostęp 31 października 2014]. Dostępny w World Wide Web: http://www.lib.cam.ac.uk/students/.

${ }^{68}$ A. Sidorczyk, A. Gogiel-Kuźmicka, dz. cyt.

69 Productions shot at the Bodleian [online] [dostęp 31 października 2014]. Dostępny w World Wide Web: http://www.bodleian.ox.ac.uk/about-us/filming/productions. 
perial College London Library, Caltech Library, Princeton University Library. Z kolei z formularza dotyczącego zamówień międzybibliotecznych skorzystały Cambridge University Library, Harvard Library, University of Chicago Library, Caltech Library oraz Princeton University Library.

Innym ciekawym rozwiązaniem było podanie kontaktu do bibliotekarzy dziedzinowych. Z tej opcji skorzystały MIT Libraries, UCL Library, Imperial College London Library, Stanford University Libraries, Yale University Library, University of Chicago Library.

Za pośrednictwem witryn Bodleian Libraries, Stanford University Libraries, University of Chicago Library użytkownik mógł także umówić się na indywidualne spotkanie z bibliotekarzem. Ciekawe rozwiązanie zastosowano w Yale University Libraries, University of Chicago Library oraz w Imperial College London Library - czytelnik mógł drogą elektroniczną zarezerwować pokoje do nauki indywidualnej i grupowej ${ }^{70}$. Z kolei Caltech Library umożliwiła tą drogą rezerwację materiałów bibliotecznych, np. książek, które będą czekały na użytkownika od 2 do 48 h ${ }^{71}$.

Innymi usługami informacyjnymi były usługi synchroniczne. $\mathrm{W}$ tym przypadku zauważono jedynie możliwość wykorzystania czatu w Stanford University Libraries ${ }^{72}$, Princeton University Libraries ${ }^{73}$, Bodleian Libraries $^{74}$, Yale University Library ${ }^{75}$ i University of Chicago Library ${ }^{76}$.

W przypadku Yale University Library ${ }^{77}$ oraz Princeton University Library $^{78}$ istniała możliwość zadania pytania bibliotekarzom za pośred-

${ }^{70}$ Yale Study Spaces Scheduling [online] [dostęp 31 października 2014]. Dostępny w World Wide Web: http://schedule.yale.edu/.

71 Library Course Reserves [online] [dostęp 31 października 2014]. Dostępny w World Wide Web: http://www.lib.uchicago.edu/e/using/reserve/.

72 Ask us! [online] [dostęp 31 października 2014]. Dostępny w World Wide Web: http://library.stanford.edu/ask.

${ }^{73}$ Chat Live with a Librarian! [online] [dostęp 31 października 2014]. Dostępny w World Wide Web: http://library.princeton.edu/help/chat.

${ }^{74}$ Contact us [online] [dostęp 31 października 2014]. Dostępny w World Wide Web: http://www.bodleian.ox.ac.uk/about-us/contact.

${ }_{75}$ Ask Yale Library [online] [dostęp 31 października 2014]. Dostępny w World Wide Web: http://ask.library.yale.edu/.

${ }^{76}$ Ask a Librarian [online] [dostęp 31 października 2014]. Dostępny w World Wide Web: http://www.lib.uchicago.edu/e/using/reference/ask.html.

77 Ask a Librarian [online] [dostęp 31 października 2014]. Dostępny w World Wide Web: http://ask.library.yale.edu/

${ }_{78}$ Sociology Portal [online] [dostęp 31 października 2014]. Dostępny w World Wide Web: http://libguides.princeton.edu/content.php?pid=359253. 
nictwem wiadomości tekstowej SMS. Z kolei w Imperial College London Library można było tą drogą zgłosić wszelkie zakłócenia w czytelni ${ }^{79}$.

\section{Podsumowanie}

W dzisiejszych czasach usługi dostępne poprzez Internet stają się coraz bardziej popularne. Potencjalny czytelnik biblioteki, chcąc zapoznać się z ofertą placówki, na samym początku ogląda jej stronę WWW. Ważne jest więc, by witryna była dla niego jak najbardziej atrakcyjna i przejrzysta. Placówki w coraz większym stopniu starają się wykorzystywać narzędzia technologii Web 2.0. Mają one usprawnić obsługę, korzystanie z biblioteki oraz komunikację z nią. Dzięki wykorzystaniu nowoczesnych technologii starają się one zaspokajać indywidualne potrzeby czytelników i wpływać na ich coraz większą satysfakcję.

Z przeprowadzonej analizy 11 stron WWW wyżej wymienionych bibliotek zaobserwowano, że większość z nich już dziś dostosowała swoją ofertę do potrzeb współczesnego użytkownika. Wyniki badań są bardzo zbliżone do tych dotyczących analizy wykorzystania technologii Web 2.0 na przykładzie 20 wybranych europejskich stron internetowych bibliotek uniwersyteckich (o pracy, która zostanie opublikowana w materiałach pokonferencyjnych, wspomniano we wstępie do artykułu). Przebadane wówczas placówki wykorzystywały wiele narzędzi technologii Web 2.0, jak serwisy internetowe, kanały RSS, podcasty. W odróżnieniu od nich biblioteki poddane analizie, będącej przedmiotem niniejszego opracowania, w większym stopniu posługiwały się różnego rodzaju formularzami, np. „Zapytaj bibliotekarza”, oraz częściej korzystały z takich serwisów jak Instagram.

Zauważono, że niektóre z omówionych narzędzi technologii Web 2.0. były wykorzystywane przez biblioteki w większym stopniu. Należały do nich kanały RSS, wszelkiego rodzaju formularze i serwisy społecznościowe, takie jak Facebook oraz Twitter. Bibliotekarze starali się rozbudować OPAC 2.0. Jest on bowiem podstawowym narzędziem komu-

79 Textanattendant - Imperial College London [online] [dostęp 31 października 2014]. Dostępny w World Wide Web: http://www3.imperial.ac.uk/library/getintouch/ textanattendant. 
Tabela 1. Wykaz bibliotek poddanych analizie. Układ według QS World University

\begin{tabular}{|c|c|c|c|c|c|c|}
\hline \multicolumn{2}{|c|}{$\begin{array}{l}\text { Nazwa } \\
\text { Uniwersytetu }\end{array}$} & $\begin{array}{l}\text { Massachusetts } \\
\text { Institute } \\
\text { of Technology } \\
\text { (MIT) }\end{array}$ & $\begin{array}{l}\text { Harvard } \\
\text { University }\end{array}$ & $\begin{array}{l}\text { University } \\
\text { of Cambridge }\end{array}$ & $\begin{array}{l}\text { University } \\
\text { College } \\
\text { London } \\
\text { (UCL) }\end{array}$ & $\begin{array}{l}\text { Imperial } \\
\text { College } \\
\text { London }\end{array}$ \\
\hline \multicolumn{2}{|c|}{ Rok założenia } & 1861 & 1636 & 1209 & 1826 & 1907 \\
\hline \multicolumn{2}{|c|}{$\begin{array}{l}\text { Nazwa } \\
\text { biblioteki }\end{array}$} & MIT Libraries & $\begin{array}{l}\text { Harvard } \\
\text { Library }\end{array}$ & $\begin{array}{l}\text { Cambridge } \\
\text { University } \\
\text { Library }\end{array}$ & UCL Library & $\begin{array}{l}\text { Imperial } \\
\text { College } \\
\text { London } \\
\text { Library }\end{array}$ \\
\hline \multirow{6}{*}{ 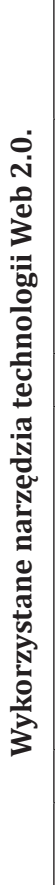 } & $\begin{array}{l}\text { Strona } \\
\text { internetowa } \\
\text { biblioteki }\end{array}$ & $\begin{array}{l}\text { http:// } \\
\text { libraries.mit. } \\
\text { edu/ }\end{array}$ & $\begin{array}{l}\text { http://lib. } \\
\text { harvard.edu/ }\end{array}$ & $\begin{array}{l}\text { http://www. } \\
\text { lib.cam.ac.uk/ }\end{array}$ & $\begin{array}{l}\text { http://www. } \\
\text { ucl.ac.uk/ } \\
\text { Library/ }\end{array}$ & $\begin{array}{l}\text { http://www3. } \\
\text { imperial.ac.uk/ } \\
\text { library }\end{array}$ \\
\hline & $\begin{array}{l}\text { Obecność na } \\
\text { serwisach } \\
\text { społeczno- } \\
\text { ściowych } \\
\text { i interneto- } \\
\text { wych }\end{array}$ & $\begin{array}{l}\text { Facebook } \\
\text { Twitter } \\
\text { Flickr }\end{array}$ & $\begin{array}{l}\text { Twitter } \\
\text { YouTube }\end{array}$ & $\begin{array}{l}\text { Facebook } \\
\text { Twitter } \\
\text { Pinterest } \\
\text { Flickr }\end{array}$ & $\begin{array}{l}\text { Facebook } \\
\text { Twitter } \\
\text { Instagram } \\
\text { YouTube }\end{array}$ & $\begin{array}{l}\text { Facebook } \\
\text { Twitter } \\
\text { Instagram }\end{array}$ \\
\hline & Blogi & Jest & 0 & Jest & Jest & 0 \\
\hline & $\begin{array}{l}\text { Katalog } \\
\text { OPAC } 2.0\end{array}$ & $\begin{array}{l}\text { Odnośnik do } \\
\text { Google Books, } \\
\text { RefWork, wy- } \\
\text { słanie opisu } \\
\text { bibliograficz- } \\
\text { nego na e-mail }\end{array}$ & $\begin{array}{l}\text { Odnośnik do } \\
\text { Google Books, } \\
\text { streszczenia } \\
\text { i spisy treści, } \\
\text { tagowanie, } \\
\text { RefWorks, } \\
\text { wysłanie opisu } \\
\text { bibliograficz- } \\
\text { nego na e-mail }\end{array}$ & $\begin{array}{l}\text { Odnośnik do } \\
\text { Google Books, } \\
\text { tagowanie, } \\
\text { RefWorks }\end{array}$ & $\begin{array}{l}\text { RefWorks } \\
\text { wysłanie } \\
\text { opisu biblio- } \\
\text { graficznego } \\
\text { na e-mai }\end{array}$ & $\begin{array}{l}\text { Odnośnik do } \\
\text { Google Books, } \\
\text { streszczenia } \\
\text { i spis treści, } \\
\text { tagowanie, } \\
\text { RefWorks, } \\
\text { wysłanie opisu } \\
\text { bibliograficz- } \\
\text { nego na e-mail }\end{array}$ \\
\hline & RSS & Jest & Jest & Jest & Jest & Jest \\
\hline & $\begin{array}{l}\text { Serwisy } \\
\text { audio }\end{array}$ & podcast & 0 & podcast & podcast & 0 \\
\hline
\end{tabular}


Rankings 2013

\begin{tabular}{|c|c|c|c|c|c|}
\hline $\begin{array}{l}\text { University of } \\
\text { Oxford }\end{array}$ & $\begin{array}{l}\text { Stanford } \\
\text { University }\end{array}$ & Yale University & $\begin{array}{l}\text { University of } \\
\text { Chicago }\end{array}$ & $\begin{array}{l}\text { California } \\
\text { Institute of } \\
\text { Technology } \\
\text { (Caltech) }\end{array}$ & $\begin{array}{l}\text { Princeton } \\
\text { University }\end{array}$ \\
\hline 1167 & 1891 & 1701 & 1890 & 1891 & 1746 \\
\hline $\begin{array}{l}\text { Bodleian } \\
\text { Libraries }\end{array}$ & $\begin{array}{l}\text { Stanford } \\
\text { University } \\
\text { Libraries }\end{array}$ & $\begin{array}{l}\text { Yale University } \\
\text { Library }\end{array}$ & $\begin{array}{l}\text { University } \\
\text { of Chicago } \\
\text { Library }\end{array}$ & $\begin{array}{l}\text { Caltech } \\
\text { Library }\end{array}$ & $\begin{array}{l}\text { Princeton } \\
\text { University } \\
\text { Library }\end{array}$ \\
\hline $\begin{array}{l}\text { http://www. } \\
\text { bodleian. } \\
\text { ox.ac.uk/ } \\
\text { bodley }\end{array}$ & $\begin{array}{l}\text { http://library. } \\
\text { stanford.edu/ }\end{array}$ & $\begin{array}{l}\text { http://web. } \\
\text { library.yale. } \\
\text { edu/ }\end{array}$ & $\begin{array}{l}\text { http://www. } \\
\text { lib.uchicago. } \\
\text { edu/e/index. } \\
\text { html }\end{array}$ & $\begin{array}{l}\text { http:// } \\
\text { library. } \\
\text { caltech.edu/ }\end{array}$ & $\begin{array}{l}\text { http://library. } \\
\text { princeton.edu/ }\end{array}$ \\
\hline $\begin{array}{l}\text { Facebook } \\
\text { Twitter } \\
\text { Google+ } \\
\text { Pinterest } \\
\text { YouTube }\end{array}$ & Twitter & $\begin{array}{l}\text { Facebook } \\
\text { Twitter }\end{array}$ & Facebook & Facebook & $\begin{array}{l}\text { Facebook } \\
\text { Twitter }\end{array}$ \\
\hline 0 & Jest & 0 & 0 & Jest & Jest \\
\hline $\begin{array}{l}\text { Odnośnik } \\
\text { do Google } \\
\text { Books, tago- } \\
\text { wanie }\end{array}$ & $\begin{array}{l}\text { Odnośnik do } \\
\text { Google Books, } \\
\text { streszczenia } \\
\text { i spisy treści, } \\
\text { RefWorks, } \\
\text { wysłanie opisu } \\
\text { bibliograficz- } \\
\text { nego na e-mail }\end{array}$ & $\begin{array}{l}\text { Odnośnik do } \\
\text { Google Books, } \\
\text { wysłanie opisu } \\
\text { bibliograficz- } \\
\text { nego na e-mai }\end{array}$ & $\begin{array}{l}\text { Odnośnik do } \\
\text { Google Books, } \\
\text { tagowanie, } \\
\text { wysłanie } \\
\text { opisu biblio- } \\
\text { graficznego na } \\
\text { e-mail }\end{array}$ & $\begin{array}{l}\text { Streszczenia } \\
\text { i spisy treści }\end{array}$ & $\begin{array}{l}\text { Odnośnik do } \\
\text { Google Books, } \\
\text { streszczenia } \\
\text { i spisy treści, } \\
\text { wysłanie opisu } \\
\text { bibliograficz- } \\
\text { nego na e-mail }\end{array}$ \\
\hline Jest & Jest & Jest & Jest & Jest & Jest \\
\hline 0 & 0 & 0 & 0 & 0 & 0 \\
\hline
\end{tabular}


nikacji między biblioteką a czytelnikiem. Pracownicy bibliotek dokładali starań, by katalogi ich bibliotek były coraz bardziej atrakcyjne i użyteczne dla czytelnika. Dlatego zamieszczali w nich m.in. streszczenia książek i umożliwiali tagowanie. Dzięki tej opcji czytelnik przed wypożyczeniem publikacji mógł zorientować się, czy jest mu ona potrzebna. Popularna była także opcja wysyłania spisów bibliograficznych na skrzynkę poczty elektronicznej. Dzięki temu użytkownik nie musiał ponownie szukać potrzebnej publikacji, miał także opis, którego mógł użyć do tworzonej przez siebie bibliografii.

Mniej wykorzystywanymi w promocji i komunikacji z użytkownikiem narzędziami były stosunkowo nowe serwisy społecznościowe, takie jak Pinterst, Instagram, Google+, Flickr. Jedynie trzy biblioteki zastosowały podcasty. Rzadko wykorzystywano także usługi synchroniczne, np. czat, ponieważ wymagało to stałej obecności bibliotekarza.

Podsumowując, wśród analizowanych stron WWW na miano lidera zasługują witryny internetowe MIT Libraries, Cambridge Library, UCL Library oraz Bodleian Libraries. Widać, że placówki te starają się wykorzystywać potencjał większości poddanych analizie narzędzi Web 2.0. Zakładały konta w powszechnie znanych serwisach społecznościowych, takich jak Facebook czy Twitter, ale także tych mniej popularnych, jak Instagram, Pinterest. Stosowały także podcasty. Dzięki swoim działaniom starały się być jak najbardziej atrakcyjnymi i nowoczesnymi placówkami dla użytkowników. Dążyły do tego, by na bieżąco informować czytelników o swoich usługach. Wychodziły naprzeciw ich oczekiwaniom, wykorzystując nowoczesną technologię. W coraz większym stopniu stosowały również wszelkiego rodzaju formularze elektroniczne, które pozwalały na kontakt z użytkownikiem za pośrednictwem sieci.

Pozostałe witryny WWW nie odbiegały znacząco od wyżej wymienionych. Nie dziwi wysoka jakość wszystkich analizowanych stron WWW. Były to bowiem biblioteki uczelni, które znalazły się w rankingu najlepszych uniwersytetów na świecie, a co za tym idzie - starały się, by jakość ich usług była na jak najwyższym poziomie. 


\section{Bibliografia}

About us. Mission [online] [dostęp 31 października 2014]. Dostępny w World Wide Web: http://libraries.mit.edu/about/.

Ask a Librarian [online] [dostęp 31 października 2014]. Dostępny w World Wide Web: http://www.lib.uchicago.edu/e/using/reference/ask.html.

Ask us! [online] [dostęp 31 października 2014]. Dostępny w World Wide Web: http://library.stanford.edu/ask.

Bednarek-Michalska Bożena, Ocena jakości bibliotekarskich serwisów informacyjnych udostępnianych w Internecie. „Biuletyn EBIB” [online] 2002, nr 2 (31) [dostęp 31 października 2014]. Dostępny w World Wide Web: http://www. ebib.pl/biuletyn-ebib/31/a.php?bednarek_michalska.

Bigo Łukasz, Web 2.0 - ewolucja, rewolucja czy... anarchia?! [online] [dostęp 31 października 2014]. Dostępny w World Wide Web: http://www.idg.pl/ news/85027.html.

Blogs at UCL Library Services [online] [dostęp 31 października 2014]. Dostępny w World Wide Web: http://blogs.ucl.ac.uk/events/about-this-blog//.

Bodleian Libraries University of Oxford [online] [dostęp 31 października 2014]. Dostępny w World Wide Web: http://www.bodleian.ox.ac.uk/home.

Caltech Library [online] [dostęp 31 października 2014]. Dostępny w World Wide Web: http://library.caltech.edu/.

Caltech Library Course Offerings - Spring '14 Classes [online] [dostęp 31 października 2014]. Dostępny w World Wide Web: http://library.caltech.edu/ learning/.

Caltech Library news and updates [online] [dostęp 31 października 2014]. Dostępny w World Wide Web: http://library.caltech.edu/news/index.php/ archives/date/2005/01.

Cambridge University Library [online] [dostęp 31 października 2014]. Dostępny w World Wide Web: http://www.lib.cam.ac.uk/.

Cambridge University Library blogs [online] [dostęp 31 października 2014]. Dostępny w World Wide Web: http://www.lib.cam.ac.uk/blogs/index.php. Casey Michael, Librarians without borders [online] [dostęp 31 października 2014]. Dostępny w World Wide Web: http://www.librarycrunch.com/2005/09/ librarians_without_borders.html.

Chat Live with a Librarian! [online] [dostęp 31 października 2014]. Dostępny w World Wide Web: http://library.princeton.edu/help/chat. 
Contact us [online] [dostęp 31 października 2014]. Dostępny w World Wide Web: http://www.bodleian.ox.ac.uk/about-us/contact.

Derfert-Wolf Lidia, Blogi i RSS dla bibliotekarzy i bibliotek . „Biuletyn EBIB” [online] 2007, nr 7 (88) [dostęp 31 października 2014]. Dostępny w World Wide Web: http://www.ebib.info/2007/88/a.php?derfert.

Derfert-Wolf Lidia, Elektroniczne usługi informacyjne typu pytanie-odpowiedź: światowe trendy i doświadczenia bibliotek. „Biuletyn EBIB” [online] 2006, nr 1 (71) [dostęp 31 października 2014]. Dostępny w World Wide Web: http://www.ebib.info/2006/71/derfert.php.

Filas Matylda, Elektroniczna komunikacja między bibliotekami a użytkownikami [online] [dostęp 31 października 2014]. Dostępny w World Wide Web: http://skryba.inib.uj.edu.pl/wydawnictwa/e06/filas.pdf.

Filipczak Małgorzata, Jak daleko stąd do nowoczesności - w stronę biblioteki drugiej generacji. „Biuletyn EBIB” [online] 2008, nr 1 (92) [dostęp 31 października 2014]. Dostępny w World Wide Web: http://www.ebib.info/2008/92/a. php?filipczak.

Gmiterek Grzegorz, Biblioteka w środowisku społecznościowego Internetu: biblioteka 2.0, Warszawa 2012.

Gmiterek Grzegorz, Library 2.0. Możliwości zastosowania Web 2.0 w bibliotekach polskich. „Biuletyn EBIB” [online] 2007, nr 4 (85) [dostęp 31 października 2014]. Dostępny w World Wide Web: http://www.ebib.info/2007/85/a. php?gmiterek.

Gmiterek Grzegorz, Library 2.0: nowe wyzwanie dla polskich bibliotek, [w:] Oblicza Internetu: architektura komunikacyjna, Elbląg 2007, s. 195-204.

Google, Facebook i Allegro traca. NK.pl wypadła z top10 [online]. wirtualnemedia. pl [dostęp 31 października 2014]. Dostępny w World Wide Web: http:// www.wirtualnemedia.pl/artykul/google-facebook-i-allegro-traca-nk-plwypadla-z-top10\#.

Harvard Library [online] [dostęp 31 października 2014]. Dostępny w World Wide Web: http://lib.harvard.edu/.

Hetman Jacek, Modele serwisów społecznościowych [online]. Warszawa: Polska Agencja Rozwoju Przedsiębiorczości 2009, 10 s. [dostęp 31 października 2014]. Dostępny w World Wide Web: http://www.web.gov.pl/g2/ big/2010_02/fe231c5914c783f94d682ba79379bac8.pdf.

Imperial College London Library [online] [dostęp 31 października 2014]. Dostępny w World Wide Web: http://www3.imperial.ac.uk/library. 
Imperiallibrary [online] [dostęp 31 października 2014]. Dostępny w World Wide Web: http://instagram.com/imperiallibrary.

Information Skills Training [online] [dostęp 31 października 2014]. Dostępny w World Wide Web: http://www.ucl.ac.uk/library/infoskill.shtml.

Instagram [online] [dostęp 31 października 2014]. Dostępny w World Wide Web: http://instagram.com/\#.

Ioalibrary [online] [dostęp 31 października 2014]. Dostępny w World Wide Web: http://instagram.com/ioalibrary.

Jaskowska Bożena, Dudczak Adam, Library 2.0 - rewolucja i przełom, czy kolejny etap rozwoju współczesnego bibliotekarstwa?, „Przegląd Biblioteczny” 2007, z. 3, s. 354-365.

Koszowska Agnieszka, Jack Maness o teorii Biblioteki 2.0 oraz o tym, co Web 2.0 oznacza dla bibliotek. „Biuletyn EBIB” [online] 2007, nr 4 (85) [dostęp 31 października 2014]. Dostępny w World Wide Web: http://www.ebib. info/2007/85/a.php?koszowska.

Library Course Reserves [online] [dostęp 31 października 2014]. Dostępny w World Wide Web: http://www.lib.uchicago.edu/e/using/reserve/.

Library news online [online] [dostęp 31 października 2014]. Dostępny w World Wide Web: http://www.ucl.ac.uk/library/Newsletter/archive.shtml.

Library Staff News and Events [online] [dostęp 31 października 2014]. Dostępny w World Wide Web: http://library.harvard.edu/blog/harvard-library.

Maness Jack M., Library 2.0 Theory: Web 2.0 and Its Implications for Libraries [online] [dostęp 31 października 2014]. Dostępny w World Wide Web: http://www.webology.ir/2006/v3n2/a25.html.

Miller Claire Cain, Another Try by Google to take on Facebook. „The New York Times Business Day Technology" [online] 2011, June [dostęp 31 października 2014]. Dostępny w World Wide Web: http://www.nytimes.com/2011 /06/29/technology/29google.html?pagewanted=all\&_r=0.

Miller Maria, Mroczek Elżbieta, Profil użytkownika i inne elementy Web $2.0 \mathrm{w}$ bibliotekach cyfrowych. „Biuletyn EBIB” [online] 2007, nr 7 (88) [dostęp 31 października 2014]. Dostępny w World Wide Web: http://www.ebib. info/2007/88/a.php?miller_mroczek.

MIT Libraries [online] [dostęp 31 października 2014]. Dostępny w World Wide Web: http://libraries.mit.edu/.

MIT Libraries news [online] [dostęp 31 października 2014]. Dostępny w World Wide Web: http://libraries.mit.edu/news/date/2014/01/. 
Mudd Manuscript Library Blog [online] [dostęp 31 października 2014]. Dostępny w World Wide Web: https://blogs.princeton.edu/mudd/.

O’Reilly Tom, What is Web 2.0 [online] [dostęp 31 października 2014]. Dostępny w World Wide Web: http://www.oreillynet.com/pub/a/oreilly/tim/news/2005/09/30/what-is-web-20.html.

Ostrowska Danuta, Od Web 2.0 do Biblioteki 2.0, „Bibliotekarz” 2008, nr 3, s. 10-13.

Pinterest [online] [dostęp 31 października 2014]. Dostępny w World Wide Web: http://about.pinterest.com/en

Piotrowicz Grażyna, Bibliotekarz a „użytkownik - klient” we współczesnej bibliotece uczelnianej. W: Czytelnik czy klient? Ogólnopolska konferencja bibliotekarzy, Toruń, 4-6 grudnia 2003 r. (Materiały konferencyjne EBIB, nr 7) [online]. Warszawa: Komisja Wydawnictw Elektronicznych SBP, 2003 [dostęp 31 października 2014]. Web: http://ebib.oss.wroc.pl/matkonf/ torun/piotrowicz.php.

Podcast - a co to jest? [online] [dostęp 31 października 2014]. Dostępny w World Wide Web: http://podcastsportowy.wordpress.com/podcast-a-co-to-jest/. Princeton University Library [online] [dostęp 31 października 2014]. Dostępny w World Wide Web: http://library.princeton.edu/.

Productions shot at the Bodleian [online] [dostęp 31 października 2014]. Dostępny w World Wide Web: http://www.bodleian.ox.ac.uk/about-us/filming/productions.

Projects, events and training [online] [dostęp 31 października 2014]. Dostępny w World Wide Web: http://www.ucl.ac.uk/library/open-access/events. QS World University Rankings 2013 [online] [dostęp 31 października 2013]. Dostępny w World Wide Web: http://www.iu.qs.com/university-rankings/ world-university-rankings/.

Sawicka Dagmara, Funkcje witryny internetowej biblioteki akademickiej, „Praktyka i Teoria Informacji Naukowej i Technicznej” 2005, nr 1, s. 13-19.

Sidorczyk Anna, Gogiel-Kuźmicka Anna, Web 1.0, Web 2.0, czy może już Web 3.0? narzędzia i technologie informacyjno-komunikacyjne stosowane na stronach WWW bibliotek technicznych szkół wyższych w Polsce. „Biuletyn EBIB” [online], 2012, nr 2 (129) [dostęp 31 października 2014]. Dostępny w World Wide Web: http://www.ebib.pl/images/stories/numery/129/129_sidorczuk.pdf.

Sociology Portal [online] [dostęp 31 października 2014]. Dostępny w World Wide Web: http://libguides.princeton.edu/content.php?pid=359253. 
Stanford University Libraries [online] [dostęp 31 października 2014]. Dostępny w World Wide Web: http://library.stanford.edu/.

Ścisłowski Robert, RSS: wiedzieć wszystko w ciagu 5 minut! [online] [dostęp 31 października 2014]. Dostępny w World Wide Web: http://www.pcworld. $\mathrm{pl} / \mathrm{news} / 80538$.html.

Textanattendant - Imperial CollegeLondon [online] [dostęp 31 października 2014]. Dostępny w World Wide Web: http://www3.imperial.ac.uk/library/ getintouch/textanattendant.

Theme: Information Skills [online] [dostęp 31 października 2014]. Dostępny w World Wide Web: http://www.training.cam.ac.uk/cul/theme/infoskills?providerId=119246.

Twitter - o nas [online] [dostęp 31 października 2014]. Dostępny w World Wide Web: https://twitter.com/about.

UCL Library services [online] [dostęp 31 października 2014]. Dostępny w World Wide Web: http://www.ucl.ac.uk/library/.

University of Chicago Library [online] [dostęp 31 października 2014]. Dostępny w World Wide Web: http://www.lib.uchicago.edu/e/index.html.

Video tutorials \& works hops [online] [dostęp 31 października 2014]. Dostępny w World Wide Web: http://libguides.mit.edu/video/.

Video tutorials and workshops [online] [dostęp 31 października 2014]. Dostępny w World Wide Web: http://libguides.mit.edu/video.

Videos [online] [dostęp 31 października 2014]. Dostępny w World Wide Web: http://www.ucl.ac.uk/library/video.shtml.

Walkowska Justyna, Jeśli nie Web 2.0, to co? „Biuletyn EBIB” [online] 2012, nr 2 (129) [dostęp 31 października 2014]. Dostępny w World Wide Web: http:// www.nowyebib.info/images/stories/numery/129/129_walkowska.pdf. Welcome to the University Library [online] [dostęp 31 października 2014]. Dostępny w World Wide Web: http://www.lib.cam.ac.uk/students/.

What's on [online] [dostęp 31 października 2014]. Dostępny w World Wide Web: http://www.bodleian.ox.ac.uk/whats-on.

Workshops and Classes [online] [dostęp 31 października 2014]. Dostępny w World Wide Web: http://ox.libguides.com/content.php?pid=289070\& sid $=2376530$.

Yale Study Spaces Scheduling [online] [dostęp 31 października 2014]. Dostępny w World Wide Web: http://schedule.yale.edu/.

Yale University Library [online] [dostęp 31 października 2014]. Dostępny w World Wide Web: http://web.library:yale.edu/. 
Yale University Library News [online] [dostęp 31 października 2014]. Dostępny w World Wide Web: http://www.library.yale.edu/librarynews/.

\section{The use of Web 2.0 technologies by libraries from the best universities based on QS World University Rankings 2013}

ABSTRACT: Examined procedure of using Web 2.0 technologies on the web libraries of top 10 universities according to the QS World University Rankings 2013. The work involved the analysis of tools which simultaneously improve their mutual communication. There were examined created by the libraries: discussion forums, RSS channels, the presence on social networks (Facebook, Twitter), blogging instant messengers. Examined the degree of usage of Web 2.0 technologies by the libraries and their purpose. The research was done in the period between 1st January and 31st July 2014.

KEYWORDS: communication, library, library promotion, library's websites, social networks, Web 2.0. 